\title{
PENYULUHAN TEKNIK PENGOLAHAN LIMBAH PETERNAKAN SAPI POTONG DI KELOMPOK PETERNAK PUTRA NUSA, DESA KONDANGDJAJA, KECAMATAN CIJULANG, KABUPATEN PANGANDARAN
}

\author{
Novi Mayasari ${ }^{1}$, Indra Firmansyah ${ }^{2}$, dan M. Rifqi Ismiraj ${ }^{1}$ \\ ${ }^{1}$ Departemen NutrisiTernak dan Teknologi Pakan, Fakultas Peternakan, Universitas Padjadjaran \\ ${ }^{2}$ Fakultas Teknologi Industri Pertanian, UniversitasPadjadjaran \\ E-mail: novi.mayasari@unpad.ac.id
}

\begin{abstract}
ABSTRAK. Salah satu produk samping dari keseluruhan aktivitas produksi sapi potong adalah limbah peternakan. Beberapa penelitian terdahulu melaporkan bahwa limbah peternakan sapi potong dapat dimanfaatkan menjadi produk yang ramah lingkungan sekaligus bernilai ekonomis. Informasi ini dirasa perlu untuk dibagikan kepada peternak sapi potong. Kelompok Peternak Putra Nusa adalah salah satu kelompok peternak yang memiliki populasi yang cukup besar, yang terletak di Desa Kondangdjaja, Kecamatan Cijulang, Kabupaten Pangandaran. Sebagai bentuk pembagian informasi, maka dilakukanlah kegiatan penyuluhan teknik pengolahan limbah peternakan sapi potong di daerah tersebut. Tujuan dari kegiatan penyuluhan ini adalah meningkatnya pengetahuan peternak mengenai jenis-jenis limbah peternakan, dampak limbah peternakan yang tidak terolah terhadap lingkungan, alternatif produk yang dapat dihasilkan dari pengelolaan limbah, dan teknologi pengolahanlimbah peternakan sapi potong. Kegiatan penyuluhan berhasil dilaksanakan dengan mencapai target luaran yaitu peternak dapat menjelaskan jenis-jenis limbah peternakan, dampak limbah peternakan yang tidak terolah terhadap lingkungan, alternatif produk yang dapat dihasilkan dari pengelolaan limbah, dan teknologi pengolahanlimbah peternakan sapi potong.
\end{abstract}

Kata kunci: Sapi potong; limbah; teknologi pengolahan; penyuluhan.

ABSTRACT. One of the by-products of beef cattle production activities is livestock waste. Previous studies reported that beef cattle farm waste can be used as a product that is environmentally friendly and economically valuable. This information is deemed necessary to be transferredto beef cattle farmers. Putra Nusa Farmers Group is agroup of farmers who haslarge population of cattles, which is located in Kondangdjaja Village, Cijulang District, Pangandaran Regency. As a form of information sharing, a counseling program was conducted on the techniques of waste management in beef cattle farms in the area. The purposes of this counseling program areto increase farmers' knowledge about the types of livestock waste, the impact of farm waste that is not treated on the environment, alternative products that can be produced from waste management, and technologies for managing waste management ofbeef cattle. Counseling activities have been carried out successfully by achieving output targets, in which farmers can explain the types of livestock waste, the impact of farm waste that is not treated on the environment, alternative products that can be produced from waste management, and technologiesfor managing waste management for beef cattle.

Key words: Beef cattle; waste; processing technology; counseling.

\section{PENDAHULUAN}

Salah satu produk samping dari keseluruhan aktivitas produksi sapi potong adalah kotoran sapi atau manure. Manure adalah salah satu materi yang berbahaya bagi lingkungan jika tidak dikelola dengan baik. Hal ini dikarenakan manure hewan mengandung nitrogen $(\mathrm{N})$ dan fosfor $(\mathrm{P})$ dalam konsentrasi tinggi yang dapatmenyebabkan ketidakseimbangan nutrient di lingkungan(Abdeshahian, Lim, Ho, Hashim, \& Lee, 2016). Lebih jauh lagi, manure hewan dapat mengandung residu dari materi berbahaya, seperti hormon pertumbuhan (growth hormone), antibiotik, dan logam berat. Selain itu, mikroorganisme di dalam manure dapat mengkontaminasi lingkungan, yang dikhawatirkan akan mengakibatkan terjangkitnya wabah penyakit untuk manusia. Berkaitan dengan ini, pembuangan manure hewan tanpa pengolahan dilaporkan telah mengakibatkan polusi lingkungan, dengan cara mengkontaminasi udara, tanah, dan sumber air (Thien Thu et al., 2012).
Di lain pihak, beberapa penelitian menyatakan bahwa manure dapat dijadikan sumber daya yang bermanfaatjikadikelola dengan baik. Manuretersebut dapat dapat dimanfaatkan sebagai sumber bahan bakar dalam bentuk biogas, dan juga sebagai pupuk organik yang dapat digunakan di lahan pertanian. Sebagian besar peternak belum memiliki wawasan mengenai alternatif pemanfaatan manure hewan, terlebih tentang metode yag tepat untuk memproses alternatif pemanfaatan ini. Oleh karenanya transfer informasi mengenai topik ini diperlukan untuk dapat memperbaiki lingkungan, sekaligus menawarkan alternatif keuntungan ekonomis bagi para peternak dengan cara melakukan pengolahan manure hewan.

Kelompok Peternak Putra Nusa (KPPN) adalah salah satu kelompok peternak yang berlokasi di Desa Kondangdjaja, Kecamatan Cijulang, Kabupaten Pangandaran. Tujuan utama KPPN adalah pembibitan dan perkembangbiakan sapi potong. Kegiatan utama di KPPN adalah melakukan perencanaan dan pelaksanaan perkembangbiakan sapi 
potong, yang kemudian dilakukan pemeliharaan dari lahir hingga mencapai umur yang mencukupi untuk digemukkan oleh pelaku usaha penggemukan. KPPN pada awalnya mendapatkan bantuan modal awal berupa bibit sapi potong sebanyak 70 ekor dari Pemerintah Provinsi Jawa Barat, yang kemudian dilakukan pembagian bibit sapi potong tersebut kepada seluruh anggotanya. Jumlah anggota KPPN adalah sebanyak 35 orang, sehingga setiap orang dialokasikan untuk memiliki 2 ekor sapi.

Salah satu permasalahan yang nyata di KPPN adalah rendahnya pengetahuan peternak mengenai pengelolaan limbah ternak sapi potong. Pada saat survei dilakukan di KPPN, ditemukan bahwa limbah ternak sapi potong dibuang langsung ke sungai/ muara, sehingga sangat berpotensi mencemari lingkungan. Oleh karena itu pengetahuan tentang metode pengelolaan limbah peternakan sapi potong dan pemanfaatannya diperlukan oleh para peternak. Dikarenakan terdapat beberapa metode pengolahan limbah ternak sapi potong, maka dirasa perlu untuk dilakukan penyuluhan tentang topik pengelolaan limbah peternakan sapi potong. Tujuan dari kegiatan penyuluhan ini adalah meningkatnya pengetahuan peternak dalam hal pengelolaan limbah peternakan, sehingga peternak dapat mengaplikasikannya di peternakannya. Jika peternak dapat mengaplikasikan pengetahuannya mengenai pengelolaan limbah peternakan sapi potong, diharapkan pencemaran limbah dari aktivitas peternakan akan berkurang, dan juga diharapkan dapat meningkatkan kesejahteraan peternak melalui limbah yang telah diolah menjadi produk yang lebih ekonomis.

\section{METODE}

Pengabdian kepada masyarakat dilakukan dengan metode penyuluhan dengan tujuan memperkenalkan alternatif pengelolaan limbah yang lebih bermanfaat untuk lingkungan maupun untuk peternak. Informasi yang dimasukkan ke dalam program penyuluhan meliputi: (a). Pengenalan jenis limbah ternak; (b). Pengenalan alternatif produk dari limbah ternak dan manfaatnya; (c). Metode/teknologi pengolahan limbah ternak. Untuk kemudahan transfer informasi, telah disusun modul dengan judul "Pengelolaan Limbah Sapi Potong".

Penyuluhan dilaksanakan dengan metode ceramah tatap-muka tentang informasi-informasi yang telah disebutkan di atas, dan berdiskusi secara langsung dengan peternak. Setelah dilakukan pendampingan dan penyuluhan, dilakukan tahap evaluasi berupa penilaian indikator capaian. Peternak diharapkan mampu untuk menjelaskan dan mengaplikasikan salah satu teknologi pengolahan limbah ternak sapi potong.

\section{HASIL DAN PEMBAHASAN}

Tahapsurveidilakukanuntukmencarikelompok peternak yang cocok untuk diberikan penyuluhan tentang pengolahan limbah. Selain itu juga pada tahap ini dilakukan identifikasi profil kelompok peternak dan masalah yang dimilikinya,dengan tahapan seperti yang telah dijelaskan dalam Susilawati dkk. (2014) dan Hernaman dkk. (2018). Berdasarkan hasil survei, diputuskan bahwa kegiatan penyuluhan akan dilakukan di KPPN, dengan pertimbangan kepemilikan populasi ternak yang besar (70 ekor), kondisi perkandangan yang memadai, dan tersedianya tempat yang memadai untuk dilakukan penyuluhan.

Setelah dilakukan survei di KPPN, beberapa masalah yang berhasil diidentifikasi antara lain:

a. Rendahnya wawasan peternak terhadap pengolahan limbah peternakan sapi potong dan bahaya limbah bagi lingkungan.

b. Rendahnya kesadaran peternak akan potensi limbah peternakan sapi potongyang dapat dijadikan sumber penghasilan tambahan berdasarkan beberapa jenis produk hasil pengolahan.

Berdasarkan masalah yang telah teridentifikasi maka dilakukan persiapan untuk menyusun jadwal dan materi penyuluhan. Secara simultan, komunikasi dengan perwakilan KPPN juga terus dibangun dalam rangka penyampaian informasi mengenai produk alternatif pengolahan limbah peternakan sapi potong, serta sebagai tahap koordinasi untuk persiapan teknis acara penyuluhan yang akan dilakukan.

Kegiatan penyuluhan dilakukan di Balai Pertemuan KPPN di Desa Kondangdjaja, Kecamatan Cijulang, Kabupaten Pangandaran. Kegiatan penyuluhan dilakukan dengan metode ceramah (presentasi) disertai dengan diskusi dan diakhiri dengan evaluasi. Materi dari kegiatan penyuluhan ini mengacu kepada modul penyuluhan dengan judul "Pengelolaan Limbah Sapi Potong" yang telah disusun pada masa pendampingan. Antusiasme peserta terhadap kegiatan penyuluhan cukup tinggi, dimana dihadiri 70 peserta yang terdiri dari anggota dan non-anggota KPPN.

Topik-topik yang disampaikan dalam kegiatan penyuluhan ini antara lain: (a). Pengenalan jenis limbah ternak sapi potong; (b). Pengenalan alternatif produk dari limbah ternak sapi potong dan manfaatnya; (c). Metode/teknologi pengolahan limbah ternak sapi potong.

Kegiatan penyuluhan diawali dengan pengenalan definisi limbah ternak, yaitu mengacu kepada Peraturan Pemerintah (PP) No. 18/1999 Jo. PP 85/1999, limbah didefinisikan sebagai sisa atau buangan dari suatu usaha dan/atau kegiatan manusia. Juga dijelaskan bahwa limbah tersebut dapat berupa 
limbah padat dan limbah cair seperti feses, urine, sisa pakan, embrio, kulit telur, lemak, darah, bulu, kuku, tulang, tanduk, isi rumen, air dari pembersihan ternak dan kandang.

Lebih jauh dijelaskan pembagian limbah ternak menurut Parakkasi dan Hardini (2018), di mana limbah terdiri atas:

\section{a. Manure/Kotoran Ternak}

Manure atau ekskreta adalah campuran antara feses (faeces), urin (urine), dan terkadang tercampur dengan bahan-bahan lain (seperti litter atau bedding atau material yang digunakan sebagai alas kandang) yang disengaja maupun tidak sengaja. Manure terdiri atas feses dan urin. Feses yang dihasilkan sapi dewasa bisa mencapai $20-25 \mathrm{~kg} /$ hari/ekor dan produksi urin 6-10 kg/hari/ ekor (Kemendikbud, 2017).

b. Limbah Ternak yang Berasal dari Pemrosesan Hasil Ternak.

Limbah ternak juga dapat berasal dari pemrosesan hasil ternak, yaitu setelah hewan dipelihara baik di dalam maupun di luar kandang menghasilkan produk peternakan yang bila diproses lebih lanjut akan menghasilkan limbah. Untuk peternakan sapi potong yang mana sapi potong di proses di Rumah Pemotongan Hewan(RPH), limbah yang dihasilkan dapat berupa manur, offal, isi rumen, darah, kulit, dan air pencucian.

Setelah dikenalkan dengan jenis dan pembagian limbah, para peserta diajak untuk mengenali dampak limbah yang tidak diolah yang berpotensi untuk mencemari lingkungan. Beberapa dampak lingkungan yang dikenalkan kepada para peserta penyuluhan di antaranya:

a. Limbah peternakan dapat menjadi media untuk berkembang biaknya lalat yang dapat menjadi sumber penyakit yang disebarkan lalat. Hal ini disebabkan oleh karena limbah masih mengandung nutrisi yang berpotensi mendukung perkembang biakan jasad renik dan serangga, seperti lalat.

b. Limbah ternak juga dapat mencemari perairan seperti badan sungai jika limbah tersebut dibuang ke sungai. Hal ini menyebabkan meningkatnya kadar nutrient (nitrogen) di badan sungai tersebut yang mengakibatkan terjadinya proses eutrofikasi, yang mengakibatkan terjadinya penurunan konsentrasi oksigen terlarut dikarenakan adanya hasil proses nitrifikasi yang terjadi di dalam air yang dapat mengakibatkan terganggunya kehidupan biota air.

c. Kotoran ternakjuga mengandung bakteripathogen (Salmonella spp.) yang dapat membahayakan kesehatan manusia.

d. Kandungan gas metan $\left(\mathrm{CH}_{4}\right)$ yang berasal dari proses pencernaan ternak juga dapat mengganggu lingkungan sekitar.

e. Feses dan urine dari hewan yang tertular penyakit dapat menjadi sarana penularan penyakit, misalnya saja penyakit anthrax melalui kulit manusia yang terluka atau tergores.

Kemudian peserta diajak untuk mengenali alternatif produk yang berpotensi untuk dikembangkan dengan basis pengelolaan limbah. Beberapa alternatif pengelolaan limbah yang diinformasikan kepada peternak adalah sebagai berikut:

a. Pemanfaatan limbah peternakan sapi potong untuk pakan dan media cacing tanah.

b. Pemanfaatan limbah peternakan sapi potong sebagai bahan baku pupuk organik.

c. Pemanfaatan limbah peternakan sapi potong untuk energi (biogas dan bioarang).

d. Pemanfaatan limbah peternakan sapi potong sebagai bahan baku kompos.

Materi selanjutnya adalah mengenai pemaparan teknologi yang dapat diterapkan untuk memproduksi alternatif produk-produk olahan limbah yang telah disebutkan di atas. Beberapa teknologi yang dikenalkan kepada peternak adalah:

a. Komposting

Secara alami bahan-bahan organik akan mengalami penguraian di alam dengan bantuan mikroba maupun biota tanah lainnya. Proses pengomposan yang terjadi secara alami berlangsung lama dan lambat. Oleh karena itu, teknologi-teknologi pengomposan banyak dikembangkan untuk mempercepat proses pengomposan ini, baik pengomposan dengan teknologi sederhana, sedang, maupun teknologi tinggi.

Teknologi pengomposan sampah sangat beragam, baik secara aerobik maupun anaerobik, dengan atau tanpa activator pengomposan. Aktivator pengomposan yang sudah banyak beredar antara lain OrgaDec, SuperDec, ActiComp, BioPos, $\mathrm{EM}_{4}$. Setiap aktivator memiliki keunggulan sendiri-sendiri.

b. Instalasi biogas

Biogas adalah campuran beberapa gas, tergolong bahan bakar gas yang merupakan hasil fermentasi dari bahan organik dalam kondisi anaerob, dan gas yang dominan adalah gas metan $\left(\mathrm{CH}_{4}\right)$ dan gas karbondioksida $\left(\mathrm{CO}_{2}\right)$. Biogas yang dihasilkan dapat memberikan manfaat, seperti:

1. Mengurangi ketergantungan masyarakat terhadap penggunaan minyak yang jumlahnya terbatas dan sangat mahal.

2. Mengurangi penebangan kayu (untuk kayu bakar) sehingga kelestarian hutan lebih terjaga

3. Selain menghasilkan energi, buangan (sludge) 
dari alat penghasil biogas ini juga dapat digunakan sebagai pupuk organik yang baik.

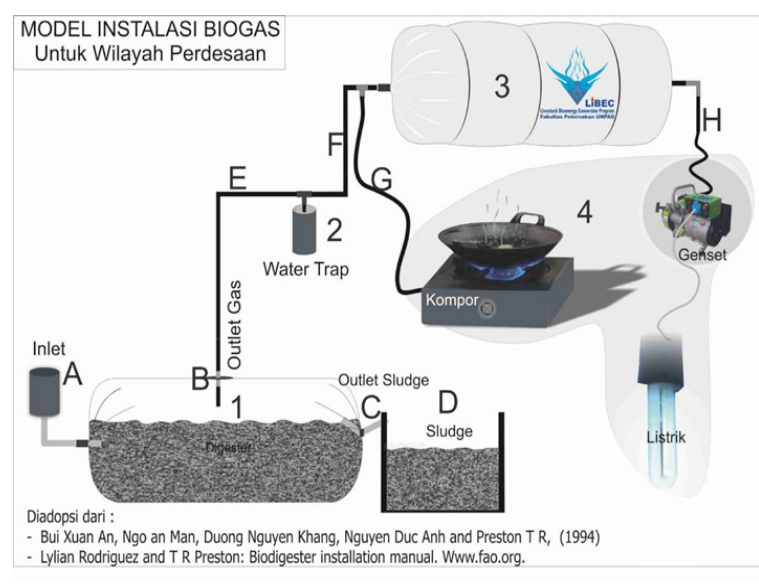

Gambar 1. Model instalasi biogas untuk rumah tangga

Secara garis besar, instalasi biogas terdiri dari (Libec, 2018):

1. Digester: tempat bahan organik dan tempat terjadinya proses pencernaan bahan organik oleh mikroba anaerob. Digester harus anaerob atau tanpa oksigen.

2. Water Trap: Sebuah tabung yang berfungsi untuk menangkap uap air yangdihasilkan dari digester agar aliran gas bio tidak terhambat, dan berfungsi juga sebagai alat pengaman.

3. Gas Holder: disebut juga penampung gas, sesuai namanya, maka fungsinya adalah untuk menampung gas yang dihasilkan dari digester yang disalurkan melalui pipa penyalur/ selang.

4. Pemanen Gas: alat ini dapat berupa kompor biogas atau genset.

5. Saluran Masuk (Inlet Bahan Organik): Sebagai tempat memasukkan bahan organik. Lebih baik dilengkapi dengan corong plastik/bak kontrol.

6. Saluran Keluar Gas (Outlet Gas): Berfungsi tempat keluarnya gas sebelum masuk ke dalam penampungan (gas holder).

7. Saluran Keluar Lumpur (Outlet Sludge): merupakan saluran untuk mengeluarkan limbah bahan organik dari digester.

8. Penampung Sludge: berfungsi untuk menampung sementara sludge/limbah bahan organik dari digester sebelum digunakan untuk memupuk tanaman.

Selang Penyalur Gas: berfungsi untuk menyalurkan gas dari digester ke water trap, gas holder dan ke alat pemanen gas (kompor biogas atau genset).

Setelah dilakukan pengenalan dan pemaparan, sesi diskusi berjalan dengan baik dan banyak peternak yang aktif bertanya. Proses diskusi ini dimaksudkan memberi kesempatan kepada para peserta untuk dapat mengklarifikasi dan meningkatkan lagi pemahaman peternak terhadap materi penyuluhan, khususnya mengenai teknologi pengolahan, karena berhubungan dengan penerapannya di lapangan.

Kegiatan penyuluhan ini meningkatkan wawasan peternak mengenai pengolahan limbah peternakan sapi potong. Pada masa survei, sebagian besar peternak mengalami kesulitan untuk memahami konsep pengelolaan limbah peternakan sapi potong. Setelah penyuluhan ini dilaksanakan, peternak mampu mengenali jenis-jenis limbah peternakan, dampak limbah peternakan yang tidak terolah terhadap lingkungan, alternatif produk yang dapat dihasilkan dari pengelolaan limbah, dan teknologi pengolahanlimbah peternakan sapi potong.

Pelaksanaan evaluasi dilaksanakan dengan cara tanya jawab secara langsung. Pertanyaanpertanyaan yang berkaitan dengan topik penyuluhan diberikan kepada peserta penyuluhan, kemudian peserta penyuluhan diwajibkan untuk menjawab pertanyaan-pertanyaan tersebut sebagai indikator keberhasilan penyuluhan. Sebanyak $80 \%$ peserta dapat menjawab pertanyaan dengan benar dan lengkap, sehingga penyuluhan dapat dikategorikan berhasil dilaksanakan.

\section{SIMPULAN}

Kegiatan penyuluhan mengenai pengelolaan limbah peternakan sapi potong berhasil dilaksanakan dengan tingkat keberhasilan $80 \%$. Peternak peserta penyuluhan memiliki antusiasme yang sangat tinggi terhadap kegiatan penyuluhan tersebut. Kegiatan penyuluhan dapat meningkatkan wawasan peternak peserta penyuluhan, tercermin dari berhasilnya peternak untuk menjelaskan jenis-jenis limbah peternakan, dampak limbah peternakan yang tidak terolah terhadap lingkungan, alternatif produk yang dapat dihasilkan dari pengelolaan limbah, dan teknologi pengolahan limbah peternakan sapi potong.

\section{UCAPAN TERIMAKASIH}

Penulis mengucapkan terima kasih yang sebesarbesarnya kepada Kelompok Peternak Putra Nusa dan perangkat pemerintah Desa Kondangdjaja yang telah memberikan kesempatan kepada tim penulis untuk melakukan kegiatan penyuluhan pengenalan pengelolaan limbah peternakan sapi potong.

\section{DAFTAR PUSTAKA}

Abdeshahian, P., Lim, J. S., Ho, W. S., Hashim, H., \& Lee, C. T. 2016. Potential of biogas production from farm animal waste in Malaysia. Renewable and Sustainable Energy Reviews, 60, 714-723. https://doi. org/10.1016/j.rser.2016.01.117. 
Hernaman, I., Budiman, A., \& Tarmidi, A. R. (2018). Perbaikan Mutu Ransum Sapi Potong Melalui Pemberian Konsentrat Berbasis Pakan Lokal di Purwakarta. Dharmakarya: Jurnal Aplikasi Ipteks Untuk Masyarakat, 7(1), 1-5. https://doi. org/ISSN 14105675.

Kementrian Pendidikan dan Kebudayaan. 2017. Limbah Ternak Ruminansia. Direktorat Jenderal Guru dan Tenaga Kependidikan.

Libec. 2018. Modul Pelatihan Pengembangan Biogas Limbah Peternakan. Fakultas Peternakan Universitas Padjadjaran Bandung. Diakses tanggal: 23 April 2018.

Parakkasi dan Hardini. 2018. Modul 1 Sistem Peternakan dan Limbahnya. Diakses tanggal: 23 April 2018.
Susilawati, I., Indriani, N. P., \& Tanuwiria, U. H. 2014. Inovasi Teknologi Pakan Sapi Potong Berbasis Sumberdaya Lokal di Desa Pasirbungur dan Purwadadi Barat Kecamatan Purwadadi Kabupaten Subang. Dharmakarya: Jurnal Aplikasi Ipteks Untuk Masyarakat, 3(1), 9-12. https://doi. org/ISSN: 14105675

Thien Thu, C. T., Cuong, P. H., Hang, L. T., Chao, N. Van,Anh, L.X., Trach, N. X., \& Sommer, S. G. 2012. Manure management practices on biogas and non-biogas pig farms in developing countries - Using livestock farms in Vietnam as an example. Journal of Cleaner Production, 27, 64-71. https:// doi.org/10.1016/j.jclepro.2012.01.006 